\title{
ANALISIS PENYEBAB PENOLAKAN PRODUK PERIKANAN INDONESIA OLEH UNI EROPA PERIODE 2007 - 2017 DENGAN PENDEKATAN ROOT CAUSE ANALYSIS
}

\author{
Rejection Analysis of the Indonesian Fishery Products to European Union \\ (2007-2017) Using Root Cause Analysis
}

\author{
Heny Irawati ${ }^{1,2}$, Feri Kusnandar ${ }^{3,4}$ dan Harsi D Kusumaningrum ${ }^{3,4}$ \\ ${ }^{1}$ Pasca Sarjana Program Studi Teknologi Pangan-Institut Pertanian Bogor Kampus IPB Darmaga, Jl. Lingkar \\ Akademik, Babakan, Dramaga, Bogor, Jawa Barat 16680 \\ ${ }^{2}$ Kementerian Kelautan dan Perikanan, Mina Bahari I, Jl. Medan Merdeka Tim. No.16 Jakarta, Indonesia \\ ${ }^{3}$ Departemen IImu dan Teknologi Pangan-Institut Pertanian Bogor, Indonesia \\ ${ }^{4}$ Seafast Center-Institut Pertanian Bogor \\ e-mail: fkusnandar@gmail.com
}

Diterima: 27 Februari 2019, Direvisi: 2 April 2019, Disetujui: 15 April 2019

\begin{abstract}
Abstrak
Produk perikanan yang diekspor ke Uni Eropa dipersyaratkan untuk diproduksi dari Unit Pengolahan Ikan (UPI) yang telah mempunyai sertifikat penerapan Hazard Analysis and Critical Control Point (HACCP) Grade A. Beberapa kasus penolakan oleh negara pengimpor masih terjadi dengan alasan ditemukannya cemaran mikrobiologi dan kimia yang melebihi ambang batas standar Uni Eropa. Tujuan penelitian ini adalah untuk mengidentifikasi penyebab penolakan dan faktor utama yang berpengaruh sebagai penyebab kasus penolakan tersebut menggunakan pendekatan Root Cause Analysis (RCA). Data yang digunakan adalah data penolakan produk perikanan yang diekspor ke Uni Eropa selama periode 2007-2017. Hasil analisis menunjukkan bahwa penyebab utama penolakan produk perikanan Indonesia adalah cemaran merkuri (33 kasus atau 31,4\% dari total penolakan) berkisar 0,54 ppm sampai 2,6 ppm, melebihi ambang batas persyaratan standar yang berlaku di Uni Eropa sebesar $0,5 \mathrm{ppm}$ untuk ikan non predator dan 1,0 ppm untuk ikan predator. Hasil analisis penyebab utama penolakan produk perikanan Indonesia setelah merkuri adalah karena kandungan histamin (16 kasus atau 15,2\% dari total penolakan) berkisar 152 ppm sampai 517 ppm melebihi standar yang ditetapkan oleh Uni Eropa bahwa dari sembilan sampel yang diambil, dua diantaranya tidak boleh melebihi $100 \mathrm{ppm}$ dengan batas tertinggi adalah 200 ppm (European Commission 2005). Cemaran merkuri terjadi karena monitoring merkuri pada penerimaan bahan baku di UPI kurang memadai dan pencemaran lingkungan perairan oleh limbah industri yang menggunakan merkuri. Cemaran histamin terjadi karena penanganan ikan tuna pada rantai produksi primer (nelayan dan pengumpul) tidak memadai dan rantai dingin tidak dijaga sejak dari atas kapal sampai ikan diterima di UPI.
\end{abstract}

Kata kunci: histamin, merkuri, penolakan, poduk perikanan, Uni Eropa

Abstract

Fishery products exported to European Union (EU) is required to be produced by Fish Processing Units that have HACCP certificate Grade A. In fact, there was several cases that the fishery products exported to EU containing heavy metal, histamine or contaminated by pathogenic bacteria exceeding the EU standards. The objective of this research was to identify the major causes and factors influencing of the rejection by applying Root Cause Analysis (RCA) approach. Data analysis used secondary data of fishery products rejections by European Union in the period of 2007 to 2017. Two major reasons of rejection were because of mercury (33 cases or $31,4 \%$ from the total rejections) found at 0,54 to 2,6 ppm which is exceeding the European standard (0,5 ppm for unpredator fish and 1,0 ppm for predator fish). Histamine contaminants (16 cases or 15,2\% form the total rejections) found at 152 ppm to 517 ppm which is exceeding the European standard (9 samples taken should not exceeding 100 ppm and the highest content should not exceed 200 ppm). Mercury contaminant occurred due to lack of monitoring in receiving step and polluted sea water by mercury used in the industrial purposes. Histamine contaminant occurred because of miss-good handling practices of fishery products in the primary production and inappropriate cool chain system within the processing chain.

Keyword: European Union, fishery products, histamine, mercury, rejections

\section{PENDAHULUAN}

Produk perikanan merupakan produk ekonomis strategis yang bisa mendukung terciptanya ketahanan dan kemandirian pangan sebagaimana tercantum dalam Undang-undang Pangan Nomor 18 Tahun 2012. Selain untuk memenuhi kebutuhan dalam negeri, produk 
perikanan juga dapat mendukung penambahan pendapatan negara melalui devisa yang dihasilkan dari ekspor produk perikanan ke negara tujuan ekspor. Rata-rata kenaikan subsektor perikanan termasuk salah satu yang terbesar dibandingkan dengan keempat subsektor pertanian lainnya. Hal ini dapat diartikan bahwa subsektor perikanan Indonesia dapat dikembangkan untuk lebih maju lagi (Lastri, 2016). Ikan termasuk dalam salah satu bahan makanan yang mengandung berbagai macam zat nutrisi, yaitu selenium, asam lemak tak jenuh, yodium, zat besi, flourida, zink dan magnesium (Mulyaningsih, 2013).

Ikan dan produk perikanan mengandung protein dan air yang cukup tinggi yang menyebabkan masuk dalam golongan bahan pangan yang mudah rusak (perishable food) karena mengandung air dan protein yang cukup tinggi. Kadar air ikan segar yang tinggi akan mempercepat proses perkembangbiakan mikroorganisme pembusuk yang terdapat di dalamnya, sehingga perlakuan yang benar setelah ikan tertangkap berperan sangat penting (Aulia dan Yennie, 2015). Faktor habitat ikan juga berpotensi menyebabkan kontaminasi dari bakteri maupun kontaminan kimia yang bisa membahayakan konsumen bila melebihi ambang batas yang diperbolehkan.

Permasalahan utama dalam kegiatan ekspor maupun impor produk pangan (termasuk produk perikanan) adalah pemberlakuan standar oleh masing-masing negara tidak sejalan dengan yang diterapkan di beberapa industri, sehingga hal ini kadang kala menyebabkan terjadinya penolakan produk perikanan Indonesia di negara importir. Oleh karena itu, aspek mutu dan keamanan hasil perikanan merupakan hal yang sangat penting dan menentukan daya saing produk di dunia internasional, mengingat konsumen negara maju merupakan konsumen dengan tingkat kepekaan yang tinggi dalam hal mutu dan keamanan produknya (Maulana et al. 2012).

Produk perikanan melalui rantai proses yang cukup panjang sejak dari penangkapan sampai menjadi produk yang siap konsumsi. Rantai kegiatan tersebut pada hakikatnya merupakan rantai pasok yang mengalirkan bahan baku ikan menuju industri pengolahan untuk diolah kemudian didistribusikan hingga konsumen. Secara umum rantai pasok ikan laut tangkapan dimulai dari pasokan ikan hasil tangkapan dari nelayan penangkap ke pedagang pengumpul, yang kemudian memasoknya untuk kebutuhan konsumsi segar atau pada perusahaan pengolahan ikan yang menghasilkan produk olahan untuk pasar lokal maupun ekspor. Pengelolaan rantai kegiatan dari penangkapan ikan hingga konsumen yang baik secara nilai maupun biaya memungkinkan industri pengolahan ikan mencapai keunggulan daya saing yang tinggi. Pembangunan sektor kelautan dan perikanan saat ini dihadapkan pada berbagai tantangan, termasuk sektor hulu, aspek pengolahan dan pemasaran hasil perikanan, dan produk kelautan di sektor hilir (Bappenas, 2016).

UPI yang akan melakukan ekspor ke Uni Eropa harus mempunyai sertifikat penerapan HACCP Grade A yang artinya tidak ada satupun penyimpangan dengan kategori serius pada saat dilakukan inspeksi oleh otoritas kompeten dan telah mendapatkan approval number yang disetujui langsung oleh Komisi Uni Eropa. Tahapan terakhir sebelum produk diekspor adalah diterbitkannya Health Certificate $(\mathrm{HC})$ oleh otoritas kompeten untuk menjamin bahwa produk perikanan yang diekspor sudah memenuhi sistem jaminan mutu dan keamanan hasil perikanan. Bila dicermati dari persyaratan tersebut, UPI yang dapat mengekspor ke Uni Eropa adalah UPI yang mempunyai tingkat penerapan HACCP paling baik, namun masih ada beberapa penolakan oleh Uni Eropa terhadap produk perikanan Indonesia karena tidak sesuai dengan standar yang berlaku di Uni Eropa, di antaranya mengandung logam berat (merkuri, timbal dan kadmium), antibiotik (nitrofuran, chlorampenicol dan oxytetracicline) dan bakteri patogen (salmonella, vibrio parahaemolyticus dan staphylococcus enterotoxin) yang melebihi ambang batas persyaratan Uni Eropa. Oleh karena itu, harus dianalisis akar permasalahannya agar kasus penolakan dapat dihindari.

Untuk mengetahui akar permasalahan penyebab penolakan produk perikanan di Uni Eropa, penelitian ini menggunakan metode RCA. Rooney dan Heuvel (2004) mendefinisikan bahwa RCA adalah suatu proses yang didesain untuk melakukan investigasi dan mengategorikan penyebab dari suatu masalah terkait keamanan, kesehatan, lingkungan, mutu, efek produksi dan tingkat kepercayaan konsumen.

RCA sudah banyak digunakan untuk memecahkan masalah dalam bidang teknologi, perbankan, asuransi, akuntan keuangan dan industri pangan dan sejak abad 21 ini menjadi metode yang berkembang pesat implementasinya dalam pemecahan masalah. Pendekatan ini juga dapat digunakan untuk memperbaiki kesalahan sistem dan hambatan yang timbul (Batchelor, 2017).

Alasan pemilihan metode ini adalah karena salah satu langkah pokok dalam menemukan faktor penyebab utama adalah dengan melakukan identifikasi penyebab dan akar masalah sebanyak mungkin dan kemudian membuat urutan menggunakan skor, selain itu metode ini juga sudah banyak digunakan oleh berbagai sektor untuk mencari penyebab suatu permasalahan. 
Berdasarkan latar belakang diatas, maka penelitian ini dilakukan dengan tujuan untuk menemukan penyebab dan akar masalah penolakan sehingga dapat diantisipasi kedepannya agar tidak terjadi berulang dan dapat dijadikan dasar oleh otoritas kompeten dalam menyusun regulasi maupun standar.

\section{TINJAUAN PUSTAKA}

\subsection{Potensi bahaya pada produk perikanan}

\subsubsection{Bahaya kimia}

Kontaminasi logam berat terhadap ekosistem perairan telah menjadi masalah dalam kesehatan lingkungan selama beberapa dekade. Kontaminasi logam berat pada ekosistem perairan secara intensif berhubungan dengan pelepasan logam berat oleh limbah domestik, industri dan aktivitas manusia lainnya (Akbar AW et al., 2014)

Menurut Nasariang et al. (2015), mekanisme masuknya merkuri ke dalam tubuh organisme perairan dapat melalui tiga cara yaitu: melalui rantai makanan, difusi permukaan kulit dan melalui insang. Dari ketiga cara tersebut, yang paling besar kemungkinan untuk masuknya merkuri ke dalam tubuh adalah melalui rantai makanan, karena hampir $90 \%$ dari bahan beracun ataupun logam berat merkuri masuk ke dalam tubuh. Pada proses ini, fitoplankton memegang peranan penting karena fitoplankton akan menyerap merkuri organik pada waktu berlangsungnya fotosintesis. Karena merkuri masuk kedalam tubuh organisme perairan melalui rantai makanan, maka akan terjadi akumulasi dalam rantai makanan, semakin panjang rantai makanan maka semakin tinggi konsentrasi logam berat tersebut dalam tubuh ikan.

Jenis-jenis ikan predator yaitu tuna, cakalang dan swordfish memiliki potensi mengandung merkuri lebih tinggi daripada ikanikan yang lain karena ikan predator tersebut memakan ikan lain yang lebih kecil dalam rantai makanan. Oleh karena itu, ikan berukuran besar dapat mengandung merkuri melebihi ambang batas yang diperbolehkan.

Merkuri selain meracuni ikan juga bertanggung jawab terhadap keracunan bahan makanan. Merkuri dapat menyebabkan keracunan karena terjadinya akumulasi (sedikit demi sedikit) dalam tubuh yang kemudian dapat merusak susunan syaraf pusat dan beberapa enzym sehingga berakibat fatal bagi konsumen. Kandungan merkuri dalam produk perikanan tidak dapat dicegah dan dihilangkan sehingga tindakan pencegahannya melalui monitoring sebaran dan kandungannya.
Histamin merupakan komponen amin biogenik, yaitu bahan aktif yang diproduksi secara biologis melalui proses dekarboksilasi dari asam amino bebas histidin serta terdapat pada berbagai bahan pangan yaitu ikan, daging merah, keju dan makanan fermentasi (Keer et al. 2002). Histamin merupakan indikator utama keracunan scombrotoksin. Scombrotoksin adalah toksin yang dihasilkan, terutama oleh ikan-ikan famili scombridae yaitu tuna, cakalang, tongkol, marlin, mackarel, dan sejenisnya (Lehane and Olley, 2000).

Histamin terjadi karena asam amino histidin diubah oleh aktivitas enzim dekarboksilase yang dihasilkan oleh bakteri (Sunarya 2014). Lebih lanjut dijelaskan bahwa histamin bukan merupakan kontaminasi, atau tidak bisa disebut residu, melainkan hasil metabolisme asam amino histidin pada ikan scombroid oleh mikroorganisme tertentu secara alamiah ada pada hasil perikanan misalnya tuna, tongkol dan cakalang. Produk perikanan yang sering terkena penolakan di Uni Eropa karena kandungan histamin yang melebihi ambang batas adalah tuna dan golongan ikan scrombidae lainnya seperti tongkol dan cakalang.

\subsubsection{Bahaya mikrobiologi}

Bahaya mikrobiologi yang mencakup bakteri, kapang penghasil toksin, virus, protozoa maupun cacing adalah permasalahan keamanan pangan terpenting di dunia. Meskipun perkembangan teknologi pengolahan terjadi sangat pesat dan sistem penjaminan keamanan pangan terus menerus dikembangkan, patogen bawaan pangan (foodborne pathogen) terus saja menjadi penyebab utama outbreak atau Kejadian Luar Biasa (KLB) penyakit bawaan pangan (foodborne diseases) di dunia. Hal ini disebabkan beragamnya jenis mikroorganisme patogen bawaan pangan dan kemunculannya dalam pangan tidak hanya dipengaruhi oleh faktor-faktor dalam pangan tetapi juga karena sebagai makhluk hidup, patogen memiliki kemampuan adaptasi dengan lingkungannya (Dewanti, 2016).

Kasus infeksi dan keracunan produk perikanan sering terjadi akibat mengonsumsi makanan yang telah terkontaminasi, baik oleh mikroba patogen penyebab infeksi maupun mikroba promotortoksin (intoksikasi). Beberapa jenis bakteri patogen yang sering ditemukan pada produk perikanan antara lain: Vibrio parahaemolyticus dan jenis Vibrio lainnya, Escherichia coli, Aeromonas spp., Salmonella spp., Staphylococcus aureus, Listeria monocytogenes, Clostridium botulinum, C. perfringens, dan Shigella spp (Dwiyitno, 2010).

Permasalahan keamanan pangan karena patogen bawaan pangan dapat menyebabkan penyakit, turunnya kualitas hidup, dan bahkan 
kematian. Disamping itu, masalah keamanan pangan ini juga dapat berdampak pada hilangnya perdagangan, kehilangan devisa, rendahnya kepercayaan terhadap industri maupun lembaga lembaga yang berkaitan dengan pengaaturan keamanan pangan bahkan pemerintah di mata internasional (Dewanti, 2016).

Bakteri patogen dapat dengan mudah mengontaminasi ikan selama penyimpanan dan distribusi dan dapat menyebabkan penyakit bagi yang mengonsumsi (Dwiyitno, 2010). Hal ini sejalan dengan pendapat Faridz et al (2007) bahwa bahan pangan termasuk ikan umumnya dapat berperan sebagai substrat untuk pertumbuhan dan perkembangbiakan spesies mikroorganisme patogenik dan non patogenik.

Faktor yang mempengaruhi adanya mikroba adalah faktor intrinsik dan faktor ekstrinsik. Faktor intrinsik adalah faktor yang tidak dapat dikendalikan oleh usaha apapun, artinya faktor yang berasal dari ikan itu sendiri yaitu adanya komponen zat makanan yang diperlukan mikroba. Faktor ekstrinsik adalah faktor yang dapat dikendalikan oleh manusia. Keberadaan bakteri dalam suatu bahan pangan dapat ditandai dari jumlah koloni per gram bahan pangan melalui uji TPC (Total Plate Count) (Febriyanti et al., 2015).

\section{METODE PENELITIAN}

\subsection{Rekapitulasi dan analisis data penolakan produk perikanan}

Data kasus penolakan produk perikanan Indonesia yang diidentifikasi dan direkapitulasi adalah data mentah di Pusat Pengendalian Mutu, Badan Karantina Ikan dan Pengendalian Mutu (BKIPM), yaitu data kasus penolakan produk perikanan Indonesia yang dikirim melalui surat resmi oleh Komisi Uni Eropa. BKIPM adalah Otoritas Kompeten (OK) yang ditunjuk untuk melakukan pengendalian terhadap jaminan mutu dan keamanan produk perikanan yang diekspor keluar negeri, sehingga Directorate General of Health and Food Safety (DG SANTE) Komisi Uni Eropa selaku OK Uni Eropa selalu memberikan notifikasi resmi terkait kasus penolakan kepada BKIPM. Indonesia dan Uni Eropa menganut sistem kerjasama government to government ( $\mathrm{G}$ to $G)$, sehingga semua urusan terkait perdagangan kedua negara diselesaikan melalui jalur diplomasi (korespondensi antar OK).

Tahapan dalam rekapitulasi dan analisis data adalah dengan melakukan pemetaan dan pengelompokan data penolakan produk perikanan dari tahun 2007 sampai 2017 berdasarkan : a) jumlah kasus penolakan setiap tahun sejak 2007 - 2017 b) pengelompokan kategori notifikasi dari Uni Eropa c) penyebab penolakan (kimia, mikrobiologi, fisik) d) komoditi produk yang ditolak (tuna, udang, demersal, pelagis dan lain-lain), e) frekuensi penolakan. Tahapan berikutnya adalah melakukan identifikasi penyebab dominan penolakan karena cemaran kimia dan mikrobiologi dan dihitung berdasarkan persentase penyebab penolakan produk perikanan.

\subsection{Analisis permasalahan yang diduga menjadi penyebab penolakan dengan metode RCA.}

RCA didesain untuk membantu melakukan identifikasi bukan hanya "apa" dan "bagaimana" masalah bisa terjadi, tapi juga untuk menemukan "mengapa" bisa terjadi. Untuk membantu menemukan jawaban mengapa masalah yang spesifik bisa timbul dalam proses, RCA dapat dijalankan dalam 5 langkah, yaitu: (1) definisi Masalah; (2) pengumpulan data; (3) identifikasi penyebab yang mungkin; (4) identifikasi akar masalah; dan (5) penentuan solusi.

Analisis dilakukan untuk mengetahui sebaran atau trend penyebab penolakan produk perikanan dari tahun 2007 sampai 2017 yang selanjutnya digunakan sebagai bahan untuk menyusun rekomendasi terhadap kebijakan dan peraturan yang sudah ada.

Dalam tahapan ini, dilakukan identifikasi sebanyak-banyaknya penyebab yang patut diduga menimbulkan penyimpangan, kemudian memberikan skor terhadap penyebab yang dinilai paling besar pengaruhnya terhadap permasalahan. Skor dibagi menjadi 5 skala penentuan yaitu dari angka 1 sampai 5 , dimana angka 5 diberikan kepada penyebab paling berpengaruh terhadap masalah.

\section{HASIL DAN PEMBAHASAN}

\subsection{Rekapitulasi dan analisis data penolakan}

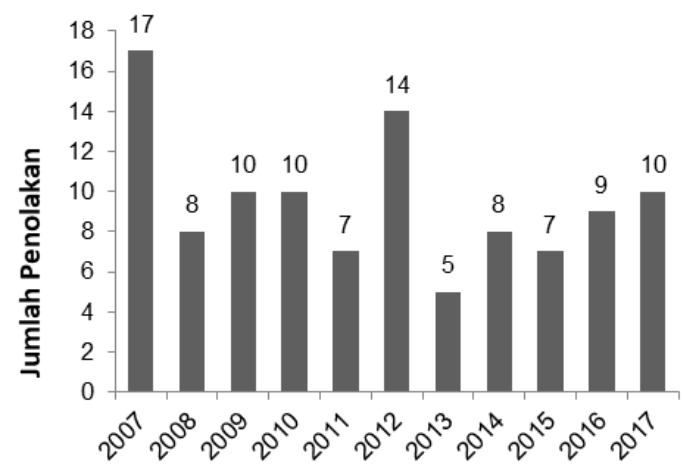

Gambar 1 Jumlah penolakan produk perikanan Indonesia oleh Uni Eropa.

Sumber: Pusat Pengendalian Mutu (Data diolah).

Penolakan produk pangan oleh Uni Eropa dialami oleh seluruh Negara pengeskpor 
produknya ke Uni Eropa. Indonesia pada 3 tahun terakhir sejak tahun 2014 - 2016 berturut-turut mengalami notifikasi penolakan sebanyak 29, 21 dan 37. Jumlah tersebut adalah untuk keseluruhan produk pangan (termasuk di dalamnya produk perikanan) yang diekspor ke Uni Eropa. Bila dibandingkan dengan negara eksportir lainnya termasuk negara anggota Uni Eropa seperti Perancis dan Jerman Indonesia masih tergolong rendah jumlah penolakan produknya, sebagai contoh untuk 3 tahun berturut-turut tersebut, Perancis mendapatkan penolakan sebanyak 104, 120 dan 118 kasus di Uni Eropa tahun 2016.

Selama tahun 2007 sampai tahun 2017 terjadi 105 kali kasus penolakan produk perikanan di Uni Eropa. Jumlah penolakan tersebut secara rinci pada setiap tahunnya. Secara lengkap perbandingan jumlah kasus setiap tahunnya dapat dilihat pada Gambar 1.

Tabel 2 Perbandingan jumlah penolakan dengan total ekspor ke Uni Eropa.

\begin{tabular}{ccccccc} 
No & Tahun & $\begin{array}{c}\text { Jumlah } \\
\text { pengiriman } \\
\text { yang } \\
\text { ditolak }\end{array}$ & $\begin{array}{c}\text { Total } \\
\text { pengiriman } \\
\text { berdasarkan } \\
\text { HC* }\end{array}$ & $\begin{array}{c}\text { Volume yang } \\
\text { ditolak (ribu kg) }\end{array}$ & $\begin{array}{c}\text { Volume total } \\
\text { ekspor (ribu } \\
\text { kg) }\end{array}$ & $\begin{array}{c}\text { Prosentase yang } \\
\text { ditolak } \\
\text { berdasarkan } \\
\text { volume (\%) }\end{array}$ \\
\hline 1 & 2011 & 7 & 2,377 & 102.1 & $71,264.1$ & 0.14 \\
2 & 2012 & 14 & 2,276 & 257.3 & $74,713.7$ & 0.34 \\
3 & 2013 & 5 & 3,361 & 61.3 & $89,544.4$ & 0.07 \\
4 & 2014 & 8 & 6,731 & 137.6 & $82,995.1$ & 0.17 \\
5 & 2015 & 7 & 6,314 & 109.2 & $71,580.7$ & 0.15 \\
6 & 2016 & 9 & 6,318 & 93.33 & $68,252.1$ & 0.14 \\
7 & 2017 & 10 & 6,138 & 111.09 & $67,853.4$ & 0.16 \\
*HC : Health Certificate
\end{tabular}

Bila dilihat dari Tabel 2, persentase volume terbesar penolakan produk perikanan terjadi pada tahun 2012 yaitu sebesar 0,34\% dengan komoditi paling dominan yang diekspor adalah udang, tuna dan cepalopod, sedangkan prosentase volume terkecil terjadi pada tahun 2013 yaitu sebesar 0,07\% dengan komoditi paling dominan yang diekspor sama dengan tahun 2012.

Uni Eropa merupakan destinasi ekspor ke 4 setelah China, Amerika serikat, dan Jepang dengan rata-rata sebanyak $8-10 \%$ dari jumlah total ekspor produk perikanan ke seluruh negara tujuan ekspor. Data sebagaimana tersaji pada Tabel 2 adalah perbandingan antara volume produk perikanan yang ditolak dengan jumlah total ekspor ke Uni Eropa. Tabel 3 menunjukkan perbandingan prosentase ekspor produk perikanan ke Uni Eropa dengan volume total ekspor produk perikanan ke seluruh negara.

Uni Eropa membagi kategori notifikasi Rapid Alert System for Food and Feed (RAFSS) berdasarkan tingkat risikonya terhadap konsumen dan distribusinya menjadi 3 kategori yaitu : alert notification, information notification dan border rejection notification. Dari 105 kasus selama 11 tahun terakhir telah terjadi 22 kasus dengan kategori alert notification, 34 kasus dengan kategori information notification dan 49 kasus dengan kategori border rejection notification. Secara lengkap informasi produk perikanan yang terkena penolakan di Uni Eropa berdasarkan kategori risikonya dapat dilihat pada Gambar 2.

\begin{tabular}{ccccccc}
\multicolumn{6}{c}{ Tabel 3 Perbandingan jumlah total ekspor dengan jumlah ekspor ke Uni Eropa. } \\
\hline No & Tahun & $\begin{array}{c}\text { Total } \\
\text { pengiriman } \\
\text { berdasarkan } \\
\text { HC }\end{array}$ & $\begin{array}{c}\text { Pengiriman } \\
\text { berdasarkan } \\
\text { HC ke UE }\end{array}$ & $\begin{array}{c}\text { Volume total } \\
\text { ekspor (ribu kg) }\end{array}$ & $\begin{array}{c}\text { Volume total ekspor } \\
\text { ke UE (ribu kg) }\end{array}$ & $\begin{array}{c}\text { Prosentase } \\
\text { ekspor ke } \\
\text { Uni Eropa } \\
\text { (\%) }\end{array}$ \\
\hline 1 & 2011 & 62,997 & 2,377 & $857,964.5$ & $71,264.1$ & 8.3 \\
2 & 2012 & 60,323 & 2,276 & $866,090.3$ & $74,713.7$ & 8.6 \\
3 & 2013 & 73,082 & 3,361 & $877,010.5$ & $89,544.4$ & 10.2 \\
4 & 2014 & 69,045 & 6,731 & $819,806.6$ & $82,995.1$ & 10.1 \\
5 & 2015 & 67,712 & 6,314 & $654,951.4$ & $71,580.7$ & 10.9 \\
6 & 2016 & 86,582 & 6,318 & $737,906.9$ & $68,252.1$ & 7.9 \\
7 & 2017 & 104,087 & 6,138 & $861,686.4$ & $67,853.4$ & 7.9 \\
\hline
\end{tabular}

Sumber : Pusat Pengendalian Mutu, KKP (Data diolah)

Menurut European Commission (2016) dalam Annual Report tahun 2016 dijelaskan bahwa yang dimaksud sebagai alert notification adalah ketika pangan, pakan atau bahan yang kontak dengan pangan terdeteksi mengandung bahaya yang serius dan sudah berada di pasar dan membutuhkan aksi cepat dari OK negara pemberi notifikasi. Alert dicetuskan oleh negara 
anggota dalam jaringan RASFF yang mendeteksi penyebab masalah dan menginisiasi tindakan yang harus diambil terhadap produk yang bermasalah tersebut, contohnya ditarik dari peredaran atau dimusnahkan. Terhadap produk
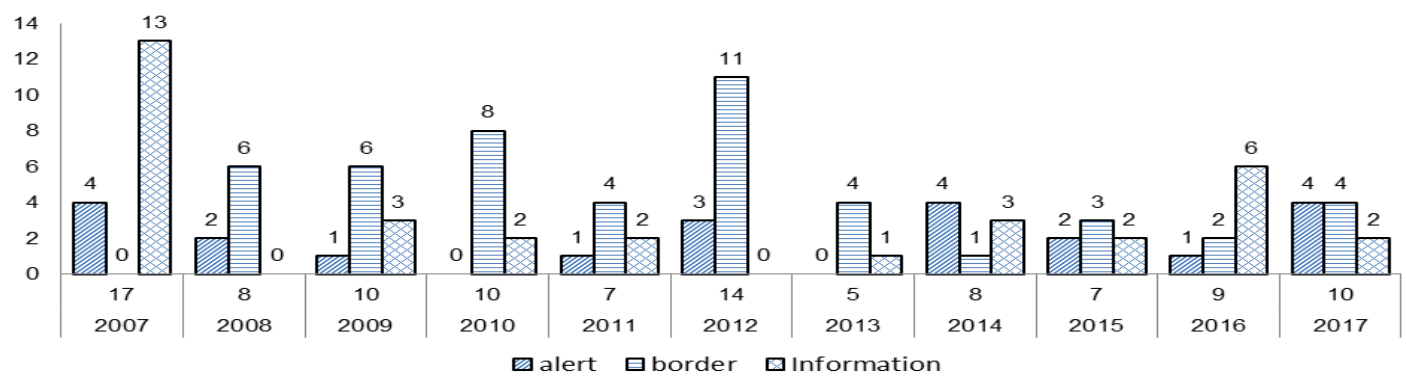

Gambar 2 Kategori penolakan berdasarkan risiko dan distribusinya.

Sumber: Pusat Pengendalian Mutu (Data diolah).

Dalam Gambar 3 penyebab penolakan produk perikanan Indonesia ke Uni Eropa dikelompokkan menjadi 5 penyebab yaitu logam berat, antibiotik, bakteri patogen, bahaya kimia selain logam berat dan penyebab lainnya yang tidak terkait dengan kategori bahaya keamanan pangan. Bahaya logam berat menduduki peringkat pertama yang menjadi penyebab penolakan dengan jumlah 42 kasus dengan merkuri sebagai penyebab paling sering terjadi yaitu 33 kasus, menyusul kadmium dengan jumlah 8 kasus dan terakhir timbal dengan jumlah 1 kasus.

Berada di urutan kedua adalah karena bahaya kimia lain dengan jumlah 21 kasus, histamin menjadi penyebab paling sering terjadi yaitu 16 kasus, kemudian $\mathrm{CO}$ sebagai penyebab paling sering kedua sebanyak 4 kasus dan terakhir karena kontaminasi mirex (organoklorin yang dijual sebagai insektisida) sebanyak 1 kasus.

Urutan ketiga penyebab penolakan adalah karena bakteri patogen yaitu sebanyak 15 kasus dengan salmonella menjadi penyebab yang paling sering terjadi yaitu 12 kasus, Vibrio parahaemoliticus sebanyak 2 kasus dan Staphylococcus aureus sebanyak 1 kasus.

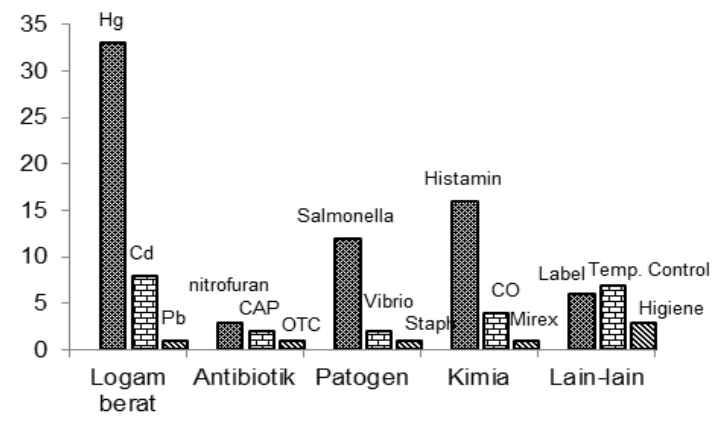

Gambar 3 Penolakan produk perikanan berdasarkan penyebab penolakan (2011-2017). Sumber: Pusat Pengendalian Mutu (Data diolah). yang sudah ditarik tersebut, masing-masing negara anggota Uni Eropa mempunyai tindakan yang berbeda sesuai dengan peraturan yang berlaku dimasing-masing negara anggota.
Produk perikanan yang diekspor ke Uni Eropa sangat beragam, mulai dari tuna dan sejenis tuna seperti cakalang dan tongkol, golongan ikan demersal seperti ikan kakap dan kerapu, golongan krustasea, moluska, golongan ikan pelagis seperti swordfish dan masih banyak lagi jenis yang lain. Produk perikanan tersebut diekspor dalam kondisi bentuk beku, fresh maupun dalam kaleng. Berikut disajikan gambar jumlah produk perikanan yang ditolak di Uni Eropa.

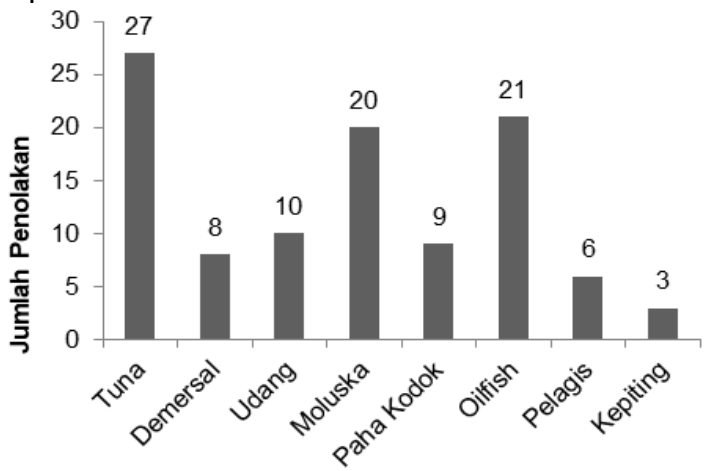

Gambar 4 Jumlah produk perikanan yang ditolak berdasarkan komoditi (2011 - 2017).

Sumber: Pusat Pengendalian Mutu (Data diolah).

Tuna adalah salah satu primadona produk perikanan yang diperdagangkan dalam maupun luar negeri yang didukung dengan nilai produksi yang cukup tinggi yaitu pada tahun 2016 produksi ikan tuna sebesar 250,9 ribu ton (Pusdatin KKP 2016). Hal ini menjadikan tuna juga sebagai produk perikanan yang paling sering mengalami kasus terkait keamanan pangan di Uni Eropa dalam 11 tahun terakhir. Penolakan produk tuna tersebut disebabkan oleh histamin (13 kasus), cO 3 kasus, merkuri (3 kasus), penanganan sanitasi yang tidak memadai (3 kasus) dan tidak terjaganya rantai dingin selama proses distribusi (5 kasus).

Dari 105 jumlah kasus penolakan selama tahun 2007 sampai tahun 2017, frekuensi 
penyebab paling sering ditolak adalah karena kandungan merkuri dengan jumlah kasus penolakan sebanyak 33 kasus hampir setiap tahun terdapat produk perikanan yang ditolak oleh Uni Eropa. Kandungan merkuri ini terdapat pada produk tuna dan sejenis tuna (tongkol dan cakalang), demersal, udang, pelagis dan Lepidocybium flavobrunneum dengan kisaran angka kandungannya antara 0,54 ppm sampai 2,6 ppm, melebihi ambang batas persyaratan standar yang berlaku di Uni Eropa yaitu sebesar $0,5 \mathrm{ppm}$ untuk ikan non predator dan $1.0 \mathrm{ppm}$ untuk ikan predator. Data sebaran frekuensi kasus penolakan sejak tahun 2007 sampai 2017 karena merkuri dapat dilihat pada gambar 5 dibawah ini.

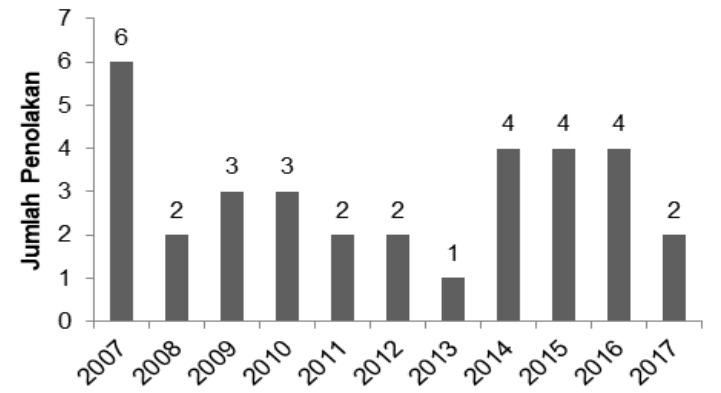

Gambar 5 Frekuensi kasus penolakan karena merkuri.

Sumber: Pusat Pengendalian Mutu (Data diolah).

Narasiang et al. (2015) menyampaikan bahwa pada umumnya, potensi akumulasi menunjukkan bahwa semakin tinggi rantai makanan maka akumulasi organisme tersebut terhadap logam berat semakin tinggi yang dihasilkan dengan semakin tinggi konsentrasi logam yang terkandung di dalam tubuh organisme tersebut. Sehingga biota seperti ikanikan besar yang telah memakan ikan-ikan yang lebih kecil yang telah terkontaminasi oleh metil merkuri, disinyalir mempunyai kandungan merkuri dalam jaringan biota perairan sesuai pula dengan proses biomagnifikasi yang terjadi dalam lingkungan perairan.

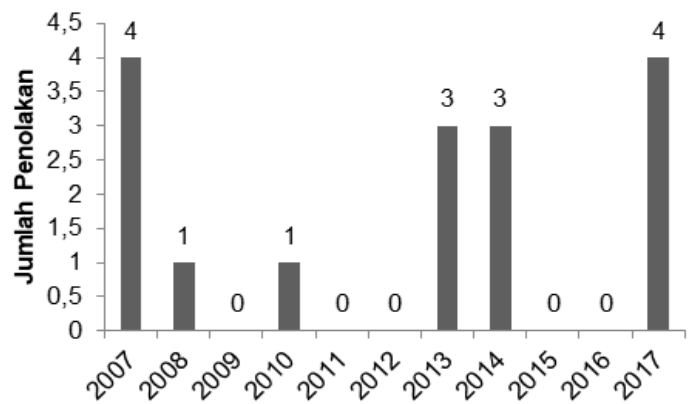

Gambar 6 Frekuensi kasus penolakan karena histamin

Sumber: Pusat Pengendalian Mutu (Data diolah).
Frekuensi penyebab penolakan paling sering ditolak pada urutan kedua setelah merkuri adalah karena kandungan histamin, yaitu sebanyak 16 kasus penolakan. Kandungan histamin yang ditolak berkisar antara 152 ppm sampai $517 \mathrm{ppm}$ pada produk ikan tuna, ikan sardin dan ikan cobia. Data sebaran frekuensi kasus penolakan sejak tahun 2007 sampai 2017 karena histamin dapat dilihat pada gambar 6 .

Ikan tuna termasuk kelompok ikan Scombridae yang dapat menghasilkan scombrotoksin yang merupakan penyebab keracunan makanan karena mengonsumsi ikan yang telah menghasilkan histamin lebih dari standar yang ditentukan. Hal ini sejalan dengan pendapat Tapia (2010), bahwa karena aspek nutrisinya, ikan tuna sebagai golongan ikan Scombridae sering menjadi penyebab keracunan makanan karena kandungan histamin. Penurunan kesegaran ikan tuna dan terbentuknya histamin terutama disebabkan oleh aktivitas enzimatis dan mikrobiologis. Salah satu penyebab penurunan kesegaran ikan tuna adalah karena penanganan ikan tuna lepas tangkap yang tidak sesuai dengan yang seharusnya. Produksi histamin pada ikan tergantung dari kadar histidin pada ikan, keberadaan bakteri penghasil enzim dekarboksilase dan kondisi lingkungan. Bakteri yang menghasilkan enzim histidin dekarboksilase yang dapat menghasilkan histamin umumnya berasal dari famili Enterobactericeae (Widiastuti dan Putro 2010).

Penyebab penolakan yang paling sering ditolak pada urutan ketiga setelah merkuri dan histamin adalah karena kandungan bakteri Salmonella yaitu sebanyak 12 kasus pada produk octopus, udang dan paha kodok. Dari hasil investigasi yang dilakukan, Salmonella diduga karena program approval supplier yang telah diprogramkan tidak dijalankan sesuai rencana sehingga tidak dapat menjamin apakah supplier masih menerapkan standar yang ditentukan, kondisi sanitasi dan higiene karyawan tidak cukup memadai, monitoring bahan baku dan metode pencucian bahan baku yang tidak memadai. Sebaran frekuensi kasus penolakan karena Salmonella dapat dilihat pada gambar 7 .

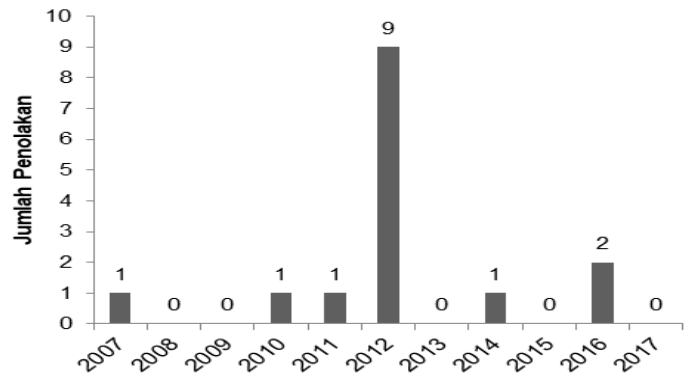

Gambar 7. Frekuensi kasus penolakan karena Salmonella

Sumber: Pusat Pengendalian Mutu (Data diolah). 
Bakteri Salmonella sering ditemukan pada kondisi perairan yang tidak sehat, terutama dalam hal daya dukung sanitasi yang kurang memadai. Bakteri Salmonella akan mencemari perairan dan juga perikanan di suatu perairan. Salmonella sp. merupakan salah satu indikator keamanan pangan, hal ini dapat menjadi indikasi dari cemaran mikroba jenis bakteri terutama bakteri Salmonella (Akbar et al. 2016).

WHO (2014) menyatakan Salmonella adalah genus bakteri yang merupakan penyebab utama penyakit bawaan makanan di seluruh dunia. Sampai saat ini masih terbatasnya studi di laboratorium, dan kurangnya penyelidikan Salmonellosis di negara berkembang membuat risiko penyakit akibat infeksi Salmonella sp. ini semakin besar.

\subsection{Penyebab penolakan berdasarkan metode RCA}

Selama 11 tahun terakhir (2007 - 2017), produk perikanan Indonesia hampir setiap tahun mengalami penolakan di Uni Eropa karena kandungan merkuri yang melebihi ambang batas persyaratan yang berlaku di Uni Eropa.
Kandungan merkuri tersebut terdapat pada produk tuna dan sejenis tuna, demersal, udang, pelagis dan swordfish dengan kisaran angka kandungannya antara 0,54 ppm sampai 2,6 ppm, melebihi standar Uni Eropa yang menetapkan tidak boleh lebih dari 0,5 ppm. Dari hasil investigasi yang telah dilakukan pada kasus tersebut, umumnya terdapat pada ikan predator dengan ukuran besar.

Pencemaran perairan yang terjadi akibat limbah-limbah merkuri dapat merusak jaringan tumbuhan dan hewan. Proses tersebut diawali dengan peningkatan konsentrasi merkuri dalam tubuh organisme yang dapat merangsang sistem enzimatik, menyebabkan keracunan dan kerusakan metabolisme dalam organ tubuh organisme (Emelda et al. 2017). Pencemaran perairan ini menjadi salah satu penyebab yang diduga menjadi penyebab kandungan merkuri pada produk perikanan. Langkah paling penting pada metode RCA adalah mengidentifikasi sebanyak-banyaknya penyebab yang patut diduga dan membuat urutan penyebab masalah tersebut seperti pada Tabel 4.

Tabel 4 Penyebab dan skor kontaminasi merkuri pada produk perikanan.

\begin{tabular}{|c|c|c|c|}
\hline No. & Penyebab & Skor & Keterangan \\
\hline 1. & $\begin{array}{l}\text { Monitoring merkuri pada penerimaan bahan } \\
\text { baku di UPI kurang memadai }\end{array}$ & 5 & $\begin{array}{l}\text { Frekuensi dan jumlah monitoring pada } \\
\text { bahan baku yang dilakukan tidak mewakili } \\
\text { keseluruhan bahan baku }\end{array}$ \\
\hline 2. & $\begin{array}{l}\text { Cemaran dari limbah merkuri terhadap } \\
\text { lingkungan akibat penggunaannya pada } \\
\text { industri kimia dan pertambangan ilegal }\end{array}$ & 4 & $\begin{array}{l}\text { Berjamurnya industri termasuk industri } \\
\text { ilegal yang menggunakan merkuri sebagai } \\
\text { bahan baku industry dan penanganan } \\
\text { limbah mengandung merkuri yang tidak } \\
\text { terkendali }\end{array}$ \\
\hline 3. & $\begin{array}{l}\text { Bahaya merkuri pada tahapan penerimaan } \\
\text { bahan baku tidak ditetapkan menjadi tahapan } \\
\text { CCP }\end{array}$ & 4 & $\begin{array}{l}\text { Karena tidak ditetapkan sebagai bahaya } \\
\text { yang signifikan, maka tidak teridentifikasi } \\
\text { sebagai tahapan CCP }\end{array}$ \\
\hline 4. & $\begin{array}{l}\text { Belum ada penanganan limbah merkuri } \\
\text { sebagai sisa dari proses industri }\end{array}$ & 3 & $\begin{array}{l}\text { Perlu aturan untuk perdagangan dan } \\
\text { distribusi }\end{array}$ \\
\hline 5. & $\begin{array}{l}\text { Belum ada pemetaan perairan yang sudah } \\
\text { tercemar merkuri }\end{array}$ & 2 & $\begin{array}{l}\text { Membutuhkan anggaran yang besar untuk } \\
\text { melakukan sampling tiap perairan sebagai } \\
\text { dasar pemetaan }\end{array}$ \\
\hline 6. & $\begin{array}{l}\text { Belum ada aturan pembatasan peredaran } \\
\text { merkuri }\end{array}$ & 2 & $\begin{array}{l}\text { Penggunaan merkuri masih bebas } \\
\text { dipasaran, siapapun bisa memperoleh }\end{array}$ \\
\hline
\end{tabular}

Dominasi penolakan produk perikanan di Uni Eropa setelah merkuri adalah karena kandungan histamin yang melebihi ambang batas. Kandungan histamin yang ditolak berkisar antara 152 ppm sampai 517 ppm pada produk ikan tuna, ikan sardin dan ikan cobia. Identifikasi penyebab yang patut diduga terdapatnya kandungan histamin diatas ambang batas sebagaimana tercantum pada Tabel 5.

Upaya untuk mempertahankan dan meningkatkan mutu ikan tuna perlu dilakukan secara intensif untuk meningkatkan akses pasar ke negara/kawasan tujuan ekspor (Widastuti dan
Putro, 2010). Lebih lanjut disarankan dalam penelitiannya bahwa diperlukan penerapan pengawasan dan penanganan rantai dingin mulai dari ikan ditangkap hingga ke proses penyimpanan oleh para nelayan dan eksportir sebagai upaya untuk mempertahankan mutu ikan tuna yang dihasilkan.

Permasalahan yang dihadapi saat ini adalah banyaknya tuna loin segar yang tidak layak untuk diekspor akibat penanganan yang kurang bagus sehingga menurunkan tingkatnya akibat tingginya kandungan histamin (Mardiah et al., 2017). 
Tabel 5 Penyebab dan skor kandungan histamin pada produk perikanan.

\begin{tabular}{|c|c|c|c|}
\hline No. & Penyebab & Skor & Keterangan \\
\hline 1. & $\begin{array}{l}\text { Penanganan ikan tuna pada rantai produksi } \\
\text { primer (nelayan dan pengumpul) tidak } \\
\text { memadai }\end{array}$ & 5 & $\begin{array}{l}\text { Penanganan terhadap bahan baku terkait SOP } \\
\text { sanitasi dan higiene pada produksi primer } \\
\text { tidak dilakukan dengan baik dan benar }\end{array}$ \\
\hline 2. & $\begin{array}{l}\text { Rantai dingin tidak dijaga sejak dari atas kapal } \\
\text { sampai ikan diterima di UPI }\end{array}$ & 5 & $\begin{array}{l}\text { Ketersediaan es dan harga menjadi } \\
\text { pertimbangan bagi nelayan dan pengumpul }\end{array}$ \\
\hline 3. & $\begin{array}{l}\text { Distribusi ikan tuna dari tiap rantai produksi } \\
\text { tidak memadai (baik terkait standar kendaraan } \\
\text { maupun suhu) }\end{array}$ & 4 & $\begin{array}{l}\text { Penggunaan kendaraan yang tidak sesuai } \\
\text { persyaratan }\end{array}$ \\
\hline 4. & $\begin{array}{l}\text { Sosialisasi terkait penanganan ikan yang baik } \\
\text { di atas kapal maupun di pemasok belum } \\
\text { merata }\end{array}$ & 3 & $\begin{array}{l}\text { Jumlah nelayan dan pemasok tersebar luas di } \\
\text { seluruh wilayah pesisir Indonesia }\end{array}$ \\
\hline 5. & $\begin{array}{l}\text { Monitoring histamin pada penerimaan bahan } \\
\text { baku tidak memadai }\end{array}$ & 3 & Sampling tidak mewakili \\
\hline 6. & $\begin{array}{l}\text { UPI menerima bahan baku dari pemasok } \\
\text { yang belum terdaftar }\end{array}$ & 3 & $\begin{array}{l}\text { Kesulitan mendapatkan bahan baku dari } \\
\text { supplier yang sudah terdaftar }\end{array}$ \\
\hline
\end{tabular}

\section{KESIMPULAN}

Hasil rekapitulasi dan analisis data penolakan produk perikanan Indonesia oleh Uni Eropa menunjukkan bahwa merkuri merupakan penyebab penolakan paling dominan dengan frekuensi penolakan hampir setiap tahun, sedangkan penyebab paling dominan kedua adalah karena histamin.

Penyebab penolakan berdasarkan metode RCA untuk merkuri adalah : 1) pencemaran merkuri pada lingkungan perairan sebagai akibat limbah industri yang menggunakan merkuri dan 2) monitoring kandungan merkuri di UPI kurang memadai. Berikutnya, penyebab penolakan karena kandungan histamin adalah : 1) penanganan ikan tuna pada produksi primer serta pengetahuan nelayan dan pekerja terkait sanitasi dan higiene tidak memadai dan 2) rantai dingin tidak terpelihara sejak dari penanganan ikan diatas kapal sampai ke UPI.

\section{UCAPAN TERIMA KASIH}

Penulis mengucapkan terimakasih kepada Pusat Pengendalian Mutu, Badan Karantina Ikan Pengendalian Mutu dan Keamanan Hasil Perikanan (BKIPM) sebagai lembaga inspeksi dan sertifikasi produk perikanan yang telah mengijinkan penulis mengolah data penolakan produk perikanan sebagai dasar penelitian ini.

\section{DAFTAR PUSTAKA}

Akbar AW, Daud A, Mallongi A. (2014). Analisis Risiko Lingkungan Logam Berat Cadmium (Cd) pada Sedimen Air Laut di Wilayah Pesisir Kota Makassar. Makassar (ID)

Aulia R, Handayani T, Yennie Y. (2015). Isolasi, identifikasi dan enumerasi bakteri
Salmonella spp. pada hasil perikanan serta resistensinya terhadap antibiotik. BIOMA 11(1): 15-33

Anonimus (2013). Shift Indonesia your Operational Excellence Guide. Retrived January 6, 2018 from http://shiftindonesia.com/5-langkahlakukan-root-cause-analysis-sebagaibagian-dari-problem-solving/

Batchelor J. (2017). Root Cause Analysis Is Transforming Audit Quality. Retrived January 6, 2018 from https://www.ifac.org/global-knowledgegateway/auditassurance/discussion/root-causeanalysis-transforming-audit-quality

[BKIPM] Badan Karantina Ikan Pengendalian Mutu dan Keamanan Hasil Perikanan. (2017). Prosedur Sertifikasi PMMT Berdasarkan HACCP. Revisi 2. Jakarta (ID)

[BPOM] Badan Pengawasan Obat dan Makanan. (2009). Penetapan Batas Maksimum Cemaran Mikroba dan Kimia dalam Makanan. Retrived March 8, 2018 from www.codexindonesia.bsn.go.id/

[BSN] Badan Standardisasi Nasional. 2006a. Ikan Segar-Bagian 1:Spesifikasi : SNI 01-2729-1-2006. Jakarta: Badan Standardisasi Nasional.

Bappenas. (2016). Kajian Strategi Industrialisasi Perikanan untuk Mendukung Pembangunan Ekonomi Wilayah. Jakarta (ID)

[CD] Commission Decision 94/324/EEC (1994). Special condition governing import of fishery and aquaculture products originating in Indonesia. Official Journal of the European Communities: The Council of The European Union. 
[EC] Regulation No 178/2002. (2002). The General Principles and Requirements Of Food Law, Establishing The European Food Safety Authority and Laying Down Procedures in Matters of Food Safety.Official Journal of the European Communities: The Council of The European Union

[EC] Commission Regulation No 1881/2006. (2006). Setting Maximum Levels for Certain Contaminants in Foodstuffs.Official Journal of the European Communities: The Council of The European Union

Dwiyitno. (2010). Identifikasi bakteri patogen pada produk perikanan dengan teknik molekuler. 5(2): 67-78

Dewanti R. (2016). Orasi IImiah Guru Besar IPB. pendekatan pasangan panganpatogen untuk membangun keamanan pangan di Indonesia. PT. Penerbit IPB Press

European Commission - Health and Food Safety. (2007). The Rapid Alert System for Food and Feed (RASFF), 2007 Annual Report. Luxembourg: Publications Office of the European Union

European Commission - Health and Food Safety. (2008). The Rapid Alert System for Food and Feed (RASFF), 2008 Annual Report. Luxembourg: Publications Office of the European Union

European Commission - Health and Food Safety. (2009). The Rapid Alert System for Food and Feed (RASFF), 2009 Annual Report. Luxembourg: Publications Office of the European Union

European Commission - Health and Food Safety. (2010). The Rapid Alert System for Food and Feed (RASFF), 2010 Annual Report. Luxembourg: Publications Office of the European Union

European Commission - Health and Food Safety. (2011). The Rapid Alert System for Food and Feed (RASFF), 2011 Annual Report. Luxembourg: Publications Office of the European Union

European Commission - Health and Food Safety. (2012). The Rapid Alert System for Food and Feed (RASFF), 2012 Annual Report. Luxembourg: Publications Office of the European Union
European Commission - Health and Food Safety. (2013). The Rapid Alert System for Food and Feed (RASFF), 2013 Annual Report. Luxembourg: Publications Office of the European Union

European Commission - Health and Food Safety. (2014). The Rapid Alert System for Food and Feed (RASFF), 2014 Annual Report. Luxembourg: Publications Office of the European Union

European Commission - Health and Food Safety. (2015). The Rapid Alert System for Food and Feed (RASFF), 2015 Annual Report. Luxembourg: Publications Office of the European Union

European Commission - Health and Food Safety. (2016). The Rapid Alert System for Food and Feed - 2016 Annual Report. Luxembourg: Publications Office of the European Union.

European Commission - Health and Food Safety. (2017). The Rapid Alert System for Food and Feed (RASFF), 2017 Annual Report. Luxembourg: Publications Office of the European Union

Emelda C, Supriatno, Ali SM. (2017). Tingkat akumulasi merkuri (hg) pada organ tubuh kelas gastropoda di kawasan perairan Sungai Sikulat Kecamatan Sawang Kabupaten Aceh Selatan. Jurnal EduBio Tropika. 5(1), April 2017: 1-53

Febriyanti D, Pujiati RS, Khoiron. (2015). Total plate count dan Staphylococcus aureus pada ikan asin manyung (Arius thallasinus) di TPI Puger Kabupaten Jember. Artikel IImiah Hasil Penelitian Mahasiswa

Keer, M, P Lawicki, S. Aguirre and C. Rayner (2002). Effect of Storage Conditions on Histamin Formation in Fresh and Canned Tuna. Victorian Government Department of Human Services.

Khasanah, NE. (2009). Adsorpsi logam berat. Jurnal Oseana. 34(4): 1-7

Lastri. (2016). Faktor menurunnya ekspor kepiting Indonesia ke Amerika Serikat. JOM Fisip. 3(2): 1-16

Lehane L dan Olley J. (2000). Histamin Fish Poisoning Revisited. 58, 1-37.

Maulana H, Afrianto E, Rustikawati I. (2012). Analisis bahaya dan penentuan titik kritis pada penanganan tuna segar utuh di PT. Bali Ocean Anugrah Linger Indonesia 
Benoa Bali. Jurnal Perikanan dan Kelautan. 3(4): 1-5

Mardiah, Kantun W, Saokani J. (2017). Pengaruh perendaman sari bawang merah (Allium cepa) untuk menghambat pembentukan histamin pada tuna loin madidihang (Thunnus albacares). Jurnal Balik Diwa. 8(1): 23-28

Mulyaningsih RTh. 2013. Monitoring logam berat dalam ikan laut dan air tawar dan evaluasi nutrisi dari konsumsi ikan. Jurnal Iptek Nuklier Ganendra. 17(1): 915

Nasariang AA, Lasut MT, Kawung NJ. Akumulasi merkuri $(\mathrm{Hg})$ pada ikan di Teluk Manado. Jurnal Pesisir dan Laut Tropis. 1(1): 8-14
Rooney JJ, Heuvel LNV. (2004). Root Cause Analysis for Beginners. Quality Progress : 45-53

Sunarya. (2014). Mutu dan Keamanan Pangan Hasil Perikanan. Cetakan pertama. CV. The Spring

Tapia GG, Quintero GB, Infante JA, Aguilar RP, Cortes JA and Ramirez JA (2013). Influence of physical damage and freezing on histamine concentration and microbiological quality of yellowfin tuna during processing. Food Sci. Technol, Campinas, 33(3): 463-467, July-Sept. 2013. http://dx.doi.org/10.1590/S010120612013005000061

World Health Organization. (2014). Salmonella. Retrived 25 Maret 2018 from http://www.who.int/topics/salmonella/en/ 
Jurnal Standardisasi Volume 21 Nomor 2, Juli 2019: Hal 149 - 160 